\title{
A Field Survey on Social Responsibility Practices Carried Out by Textile Companies in Turkey Within the Scope of Sustainable Development
}

\author{
Fatma Fusun Uysal ${ }^{1}$, Emel Demir Askeroğlu ${ }^{2} \&$ Bilge Berkhan Kastaci ${ }^{3}$ \\ ${ }^{1}$ Department of Environmental Engineering, Namık Kemal University, Tekirdag, Turkey \\ ${ }^{2}$ Department of Public Relations and Publicity, Namık Kemal University, Tekirdag, Turkey \\ ${ }^{3}$ Department of Textile Engineering, Namık Kemal University, Tekirdag, Turkey \\ Correspondence: NKÜ Çerkezköy Meslek Yüksekokulu Veliköy Mahallesi Atatürk Caddesi No: 59/A, 59500 \\ Çerkezköy, Tekirdağ, Turkey.
}

Received: July 7, 2018 Accepted: July 28, 2018 Online Published: August 21, 2018

doi:10.5539/jms.v8n3p36 URL: https://doi.org/10.5539/jms.v8n3p36

\begin{abstract}
Sustainable development is a process of change that involves institutional restructuring related with directing investments, positioning technological development and meeting the future needs as much as today's needs. The application of environmental social responsibility studies is useful for any size of textile company. A primary concern for textile companies is the amount of water used in their processes. They generate large volumes of solid and hazardous wastes. Energy is the motor behind textile processes. Energy costs used in processes are important for especially large textile companies. While institutions are producing with social responsibility awareness, fulfilling their obligations to environment has gained importance in terms of sustainable development The subject of this work introduces activities carried out by textile companies during production process, fulfilling their environmental responsibilities or not and which applications are done in the sector. Following the literature survey, a questionnaire study was conducted on textile firms operating in Turkey. From our research, it is concluded that some emerging technologies like enzymatic treatment in textile wet processing, ultrasonic treatment, electron-beam treatment, use of supercritical carbon dioxide in dyeing, electrochemical dyeing, ink-jet printing, plasma technology in textile wet processing are not used by any of companies.
\end{abstract}

Keywords: enviromental sustainability, social responsibility, sustainable environment, social responsibility of textile companies, sustainable development

\section{Introduction}

According to Welford (Welford, 2005, pp. 33-52), Corporate Social Responsibility continues to be an important business concept and in a world of increased globilisation is to be found among companies in most countries around the world. Babiak and Trendafilova (Babiak \& Trendafilova, 2011, pp. 11-24) explains that the environment has been one of the factors of greatest interest in terms of the market's attitude toward Corporate Social Responsibility in recent years. Researchers point out the environment to be the most important concern for stakeholders in a company's CSR efforts (Welford, 2005, pp. 33-52). Lulewiczs-Sas and Godlewska (Lulewicz \& Godlweska, 2013, pp. 533-538) discusses that the concept of social responsibility is related to the concept of sustainable development that obliges business entities to bear full responsibility to the protection of natural environment. They (Lulewicz \& Godlweska, 2013, pp. 533-538) point out the impementation of socially responsible activities result in the reduction of negative impacts on the environment through more efficient use of resources, reduced water consumption, lower waste disposal costs, savings from lower material and energy consumption of the enterprises' activities. Environment is one of the important pillars of corporate social responsibility approach. Corporate environmental management is about finding a balance between economic and environmental issues (http://www.unidoorg, 2017). Textile industry is extremely energy, water and chemicals intensive manufacturing. Corporate social responsibility is often covered under four headings: marketplace, workplace, environment and community. Environmental issues include energy consumption and emissions, raw material usage, waste, the volume of packaging, recycling and the use of chemicals (Jones et al., 2005, pp. 882-892). 
In a survey which, is done in Turkey "the question of to which areas of social responsibility should companies give priority" was asked. Priorities are given below (Capital, 2017))

1) Education and teaching, $29.9 \%$

2) Health and health services, $20.7 \%$

3) Support for environment an nature conservation, $11.9 \%$

4) Voluntary and chartable works, $9.1 \%$

5) Giving value to their employees, $7.2 \%$

6) Activities on human rights, $4.7 \%$

7) Culture and the arts, $4.2 \%$

8) Sport, 3.8\%

9) Support for NGO's, $3.2 \%$

10) Ethical rules and business morality, 3.1\%

As shown from figures, support for environment and nature conservation is in the third place. This means that social responsibility for environment is quite important. The research studies show that companies are increasingly paying attention to their impact on the environment and adopting management practices for reducing their negative impact on the environment.

Atılgan et al. (2012) explains that Turkish textile industry chooses the corporate social responsibility as a strategy that increases competiveness against developing markets.

In the study of Atılgan et al. (2012) five basic aims of corporate social responsibility of ten analysed textile and clothing local and foreign enterprises are summarized as:

1) Cost advantage projects which are practiced in terms of cost advantage as well as environment

2) Implementations intended for informing the public (various carnivals, publications, colloboration with organizations which aim to protect environment)

3) The projects aim at dissemination of organic raw material and product usage

4) The projects aim at reducing the chemical materials usage during production processes and product usage so that environment is protected.

5) The projects aim at choosing and supporing environment-friendly suppliers.

The most important environmental hazards from textiles are (Martinuzzi et al., 2006): use of chemicals, use of water, and generation of wastewater contaminated with hazardous substances, hazardous and toxic waste generation.

Textile industry is extemely energy, water and chemicals intensive manufactuing. The textile sector has significant environmental problems linked to the production processes, in particular the phases of of dyeing, drying and finishing. There is intense use of chemical products and natural reources in these processes (De Brito et al., 2008, pp. 534-553).

Textile and garment industry, having a share of $4 \%$ is the 5 th place in terms of generated solid waste amounts within Turkish manufaturing sector (Corporate Social Responsibility Report on Turkish Textile an Apperel Industry, 2012), Solid wastes, generated in textile factories, can be classified under two categories, one is non-hazardous wastes and the other is hazardous wastes. Faulty/rejected products, packaging wastes and other textile wastes are the examples of non-hazardous wastes. Paint containers, batteries, mineral oil, accumulators and contaminated plastics can be given as examples for hazardous wastes. The recycling of waste from textile helps to conserve resources and reduce the use of landfills. The growing textile industries face challenges to up-cycle and recycle their textile wastes into industrial products (Ahmad et al., 2016, pp. 525-535). The fashion market is characterized by the rapidty with which a product becomes outmedded. Enterprises producing clothes, shoes, bags and other accessories generate wastes at a fast rhytm, due to the continous change of collections (Cimatti, 2017, pp. 393-400).

Textile uses a large amount of water particularly in wet processing, which consists of cleaning, bleaching, dyeing and finishing (Kiran-Ciliz, 2003, pp. 481-486). Since various chemicals are used in different textile processes like pre-treatmet, dyeing, printing and finishing, the textile wastewater contains many toxic chemicals (Hasanbeigi \& Price, 2015, pp. 30-44). According to Turkish Statistical Institute, textile and garment industry is 
responsible for $15 \%$ of industrial water consumption that makes it 2 nd largest industrial water consumers within the whole Turkish manufactuing sector (Alkaya \& Demirer, 2014, pp. 595-603). The iron and steel sector account for a large share (35\%) of total industrial energy consumption followed by the cement, textile, ceramics and paper industies with shares of $19.7 \%, 5.9 \%, 4.5 \%$ and 37\% respectively (Ateş \& Durakbasa, 2012, pp. 81-91).

Altough the textile industry is not considered an energy-intensive industry; many of plants consume a significant amount of energy. For instance, it is reported that the textile industry accounted for about $4 \%$ of total manufacturing final energy use in China in 2010 but less than $2 \%$ in the U.S.A. Hasanbeigi and Price explains that around $48 \%$ of the energy input to the textile industry is lost on site (e.g., in boilers, motor system, distribution etc.). The U.S.A. textile industry is ranked as the 6th largest steam consumer amongst 15 major industrial sectors studied in the U.S.A. (Hasanbeigi \& Price, 2015, pp. 30-44). The textile sector in Turkey is Turkey's largest manufacturing industry and its largest export sector and a relatively important position in the world. Turkish textile industry is one of the oldest and biggest industrial sector in Turkey. Since this industry is energy-intensive, it is very important to minimize the energy cost and energy consumption for the textile industry (Öztürk, 2005, pp. 2424-2446).

Most consumers exhibit a willingness to incur a modest price increase in order to support environmentally and socially responsible practices (Parsa et al., 2015, pp. 250-260). They indicate that only consumers who are actively involved in environmentally and socially reponsible practices pay more.

By means of a questionnaire, this study aims to investigate the level of environmetal corporate social responsibility (ECSR) activities, ECSR investments and independents'perception in this concept. The study investigates whether companies have any projects of decreasing water usage, energy recovery and also investigates studies of waste management, usage of recycled material in production, planting activities, the selection of suppliers having environmental sensivity.

\section{Materials and Methods}

There are many different ways to develop environmental corporate social responsibility programs for companies. To learn more about environmental corporate social responsibility, a written survey was conducted with 24 textile companies from Kahramanmaraş, Çerkezköy and Çorlu in Turkey. The companies were sampled geographically from the south and west of Turkey. In the survey, we want to see different approaches taken by different companies.

The questionnaire was sent to some of companies by e-mail and a few of them were interviewed on phone. The questionnaire was evaluated in the questions of environmental protection, waste management, supplier selection with environmental sensivity, planting activities, energy and water recovery.

A set of questionnaire was formulated and designed based on the previous literature in the subject area. Yes or no questions were preffered in the survey because respondents arrive at conclusions quickly and efficiently. In the case of answering yes, the applications done in their plants were requested to explain.

\section{Results and Discussion}

Yes/No answers corresponding to each question are given in Table 1.If the answers to the questions were yes, the applications were asked.

Table 1. Yes/no answer corresponding to each question

\begin{tabular}{lll}
\hline QUESTIONS & YES \% & NO \% \\
\hline Do you make water recovery projects? & $64 \%$ & $36 \%$ \\
Do you make energy saving projects? & $86 \%$ & $14 \%$ \\
Do you make waste recycling and seperation? & $91 \%$ & $9 \%$ \\
Do you collect paper for recycling? & $95 \%$ & $5 \%$ \\
Do you collect plastics for recycling? & $95 \%$ & $5 \%$ \\
Do you collect mineral and vegatable waste oil? & $77 \%$ & $23 \%$ \\
Are batteries and electronic wastes collected? & $86 \%$ & $14 \%$ \\
Is the collection of fabric trims, that ocur as a production surplus, & $100 \%$ & \\
made for recycling? & & \\
Is the application of green chemistry (use of chemicals without & $77 \%$ & $23 \%$ \\
environmental hazard) carried out? & $82 \%$ & $18 \%$ \\
Is contaminated waste disposal and recycling made? & $77 \%$ & $23 \%$ \\
Is the usage of environment-friendly product done? & & \\
\hline
\end{tabular}




\begin{tabular}{|c|c|c|}
\hline $\begin{array}{l}\text { Is sustainable material used in the production? (For example } \\
\text { preffered use of wool and cotton according to synthetic materials?) }\end{array}$ & $77 \%$ & $23 \%$ \\
\hline Do you use recycled materials in production? & $64 \%$ & $36 \%$ \\
\hline Do you have any activity of environmental planting? & $82 \%$ & $18 \%$ \\
\hline $\begin{array}{l}\text { Do you give importance in the selection of suppliers having } \\
\text { environmental sensitivity? }\end{array}$ & $91 \%$ & $9 \%$ \\
\hline
\end{tabular}

The applications of companies are given in Table 2.

Table 2. Applications of companies

\begin{tabular}{|c|c|}
\hline QUESTION & APPLICATIONS \\
\hline Do you make water recovery projects? & $\begin{array}{l}\text { There are some works to decrease water consumption. As a result of } \\
\text { R\&D activities aimed at reducing water consumption, projects such as } \\
\text { reduction of bath water, use of cooling water in production, } \\
\text { development of existing continous working sytems. Improvements are } \\
\text { made with new technologial machines. The reuse of water is provided } \\
\text { according to the degree of pollution. The amount of fabric dyed only } \\
\text { once in dyeing machine is increased in order to reduce the water } \\
\text { consumption. }\end{array}$ \\
\hline Do you make energy saving projects? & $\begin{array}{l}\text { Less energy and resource utilization is achieved by making } \\
\text { improvements in production processes. Improvements are made with } \\
\text { technological machines for reducing energy consumption and projects } \\
\text { related to heat recovery systems are being carried out. In order to } \\
\text { decrease energy use in processes, the following projects by textile } \\
\text { companies are caried out: } \\
\text {-Switching to natural gas projects, } \\
\text {-Using hot steam heating instead of the open cabin, } \\
\text {-Switching the inverted air compressor, } \\
\text {-Revision of steam traps (to receive steam condensing as water in } \\
\text { lines), } \\
\text {-Isolation of cooling water and heating lines. Preventing losses by } \\
\text { insulating steam lines, } \\
\text {-Clean hot water production from waste hot water by using waste heat } \\
\text { recovery unit, } \\
\text {-In order to decrease electric consumption, lighting sensors were used } \\
\text { in toilets. }\end{array}$ \\
\hline Do you make waste recycling and seperation? & $\begin{array}{l}\text { The recycling of waste from textile plants helps to conserve resources } \\
\text { and reduce the use of landfills. Wastes are classified and collected } \\
\text { according to classification. }\end{array}$ \\
\hline Do you collect paper for recycling? & $\begin{array}{l}\text { Waste paper, cartoon, relic, packages etc. are collected from offices } \\
\text { and warehouses. One of companies informed that they have a paper } \\
\text { factory in their group of companies. }\end{array}$ \\
\hline Do you collect plastics for recycling & $\begin{array}{l}\text { In plants, paper, cardboard and pacakaging wastes are collected } \\
\text { seperately and sent to licensed collection and seperation plants. In } \\
\text { some plants plastics cups are collected seperately. }\end{array}$ \\
\hline Do you collect mineral and vegatable waste oil? & $\begin{array}{l}\text { Mineral waste oils are collected and given to licensed recycling } \\
\text { copanies. } \\
\text { Vegetable waste oils are colleced from factories by catering } \\
\text { companies and sent to licensed recyling companies. }\end{array}$ \\
\hline Are batteries and electronic wastes collected? & Electronic and batteries are collected seperately and sent to recycling. \\
\hline $\begin{array}{l}\text { Is the collection of fabric trims, that ocur as a production } \\
\text { surplus, made for recycling? }\end{array}$ & $\begin{array}{l}\text { Textile wastes stored in waste storage areas are given to recycycling } \\
\text { companies at regular intervals. In some of companies, these wastes } \\
\text { are sold. Masterbatch wastes are given and evaluated as input of } \\
\text { another companies. }\end{array}$ \\
\hline $\begin{array}{l}\text { Is the application of green chemistry (use of chemicals } \\
\text { without environmental hazard) carried out? }\end{array}$ & $\begin{array}{l}\text { Green chemistry restricts the use of certain chemicals. It is not } \\
\text { permitted to use restricted chemicals, which is not proper } \\
\text { ecologically. A company reported that Eco-Tex certificated chemicals } \\
\text { are used. Two companies pointed out that they have Swan Certificate } \\
\text { and organic certificate. }\end{array}$ \\
\hline Is contaminated waste disposal and recycling made? & $\begin{array}{l}\text { Contaminated materials (Contaminated sheet metal and plastics } \\
\text { barrels, contaminated cloths etc.) are collected in temporary storage } \\
\text { areas and sent to licensed companies. }\end{array}$ \\
\hline Is the usage of environment-friendly product done? & $\begin{array}{l}\text { There is a trend of usage of environment-friendly products. It changes } \\
\text { according to costomer-focused. }\end{array}$ \\
\hline
\end{tabular}




\begin{tabular}{|c|c|}
\hline $\begin{array}{l}\text { Is sustainable material used in the production? (for } \\
\text { example preffered use of wool and cotton according to } \\
\text { synthetic materials?) }\end{array}$ & $\begin{array}{l}\text { It changes according to customers'request. A few companies } \\
\text { use } \% 70-80 \text { of cotton. }\end{array}$ \\
\hline Do you use recycled materials in production? & $\begin{array}{l}\text { A company has a GRS (Global Recycle Standard Certificate) } \\
\text { certificate and manufacturing is made according to the customer's } \\
\text { order. } \\
\text { Recycled materials are used in product accessories and in packages. It } \\
\text { is also reported that projects are done to use recycled material in } \\
\text { production. }\end{array}$ \\
\hline Do you have any activity of environmental planting? & $\begin{array}{l}\text { One of the global problems is climate change, by doing carbon } \\
\text { footprint calculations; a few companies are doing projects to reduce } \\
\text { their effect on the world. Companies inform that landscaping works } \\
\text { are done at factory gardens and they are planted. One company has } \\
\text { been planning to plant its garden within next year. }\end{array}$ \\
\hline $\begin{array}{l}\text { Do you give importance in the selection of suppliers } \\
\text { having environmental sensitivity? }\end{array}$ & $\begin{array}{l}\text { Most of companies report that the most important criteria in supplier } \\
\text { pre-evaluation and annual evalution processses are human and } \\
\text { environmental health. A supplier evaluation system has been } \\
\text { established through AX Software program by one of companies. } \\
\text { Suppplier evaluation questionnaire related with environmental } \\
\text { management system, ecological declarations, APEO (Alkylphenol } \\
\text { Ethoxylates free test), Reach Conformity Certificate are requested on } \\
\text { a lot basis in each purchase order. A company that manufactures with } \\
\text { contract has mentioned that suppliers having } \\
\text { environment-consciousness are preferred by customers. } \\
\text { Environmentally conscious suppliers are preferred as a criterion in the } \\
\text { criteria of customers. }\end{array}$ \\
\hline
\end{tabular}

Based on the analysis, shown in Table 1 and Table 2, the following results were concluded:

-The energy saving projects and the water use reduction projects are carried out in recent years. Waste-heat recovery techniques are used in order to contribute to energy economy studies.

-Most of companies use environmentally friendly products and materials in their production.

-Hazardous and non-hazardous wastes are collected by nearly all companies and sent to licensed companies.

-Mineral oils and vegetable oils are collected and sent to licensed recycling companies.

-Electronic wastes and batteries are collected and sent to licensed companies.

-All companies collect textile wastes and send to recycling copanies.

-Companies restrict the use of certain chemicals and try to promote the use of Green Chemistry.

-The use of recycled materials in production is not sufficient. Recycled materials are mostly used according to customer demand and used in accessories.

-Most of companies carry out planting activites.

\section{Conclusion}

Surveys of environmental activities have identified a change in the aproaches used for solving environemntal problems by means of environemntal corporate social responsibility studies.

The application of environemental social responsibility studies is useful for any size of textile company. A primary concern for textile companies is the amount of water used in their processes. They generate large volumes of solid and hazardous wastes. Energy is the motor behind textile processes. Energy costs used in processes are important for especially large textile companies.

Hazardous and non-hazardous wastes, all of them are stored seperately in waste storage sites. Hazardous wastes are given within 180 days at the latest and non-hazardous wastes are given within one year at the latest to firms licensed from the Ministry of Environment and Urbanization.

Good housekeeping like insulating pipes is a good example to prevent energy losses. Our results show that waste-heat recovery is one of the techniques used in textile industry and conserve significant amount of fuel. It s reported that waste-heat recovery is likely to be the major conservation method to be adopted in a wide range of industries and can involve a substantial outlay of capital (Pulat et al, 2009, pp. 663-672). By using natural gas boilers, emissions are decreased. The development and application of energy-saving technologies in the sector should be emphasized to improve the efficiency of energy use. 
Kocabaş (2008) points out energy consumption is directly related to water consumption as most of the energy required to heat up process baths. Therefore, reduction in water consumption also results in enegy consumption. Results show that water minimization is slowly being adopted in textile industry but recent projects may help to reduce water use in processes.

Results point out that companies are increasing to use new technologies to make cleaner technologies competitive with the conventional processes and products. From our research, it is concluded that some emerging technologies like enzymatic treatment in textile wet processing, ultrasonic treatment, electron-beam treatment, ultrasonic treatment, use of supercritical carbon dioxide in dyeing, electrochemical dyeing, ink-jet printing, plasma technology in textile wet processing are not used by any of companies. These energy, water effiency and reduction technologies have not been commercialized (Hasanbeigi \& Price, 2015, pp. 30-44). Clean technoogies have a role in environmental corporate responsibility aims of the sector.

It is necessary to increase the consciousness about environmental sustainability for textile companies. They should be encouraged to make projects of effective use of resources. Research and development activities in textile sector should be taken into consideration in terms of the need of applying new technologies. These activities are relatively in low levels in Turkey and cleaner production services are not developed sufficiently. After years of paying no attention for sustainable and cleaner production in textile sector in Turkey, environmental issues are becoming increasingly important nowadays. High research and development costs and lack of finance are usually major barriers in developing projects.

\section{References}

Ahmad, S. Sh., Mulyadi, I. M. M., Ibrahim, N., \& Othman, A. R. (2016). The Application of Recycled Textile and Innovative Spatial Design Strategies for a Recycling Centre Exhibition Space. Procedia-Social and Behavioaral Sciences, 34, 525-535. https://doi.org/10.1016/j.sbspro.2016.10.271

Alkaya, E., \& Demirer, G. N. (2014). Sustainable texile production: a case study from a woven fabric manufacturing mill in Turkey. Journal of Cleaner Production, 69, 595-603. http://dx.doi.j.jclepro.2013.07.008

Annual Report. (2017). Responsible Entrepreneurs Achievment Programme, Environmental Management Guide. Retrieved from https://www.unido.org/resources/publications/flagship-publications/annual-report/annual-report-2017

Ateş, S. A., \& Durakbasa, N. M. (2012). Evaluation of Corporate Energy Management Practices of Energy Intensive Industries in Turkey Energy. Energy, 45, 81-91. https://doi.org/10.1016/j.energy.2012.03.032

Atılgan, T., Kanat, S., \& İlleez, A. (2012). The Environmental Effects of Corporate Social Responsibility Development of Enterprises in Textile and Clothing Sector. 1st International Fashion and Textile Design Symposium, Antalya, Turkey.

Babiak, K., \& Trendafilova, S. (2011). CSR and Environmental Responsibility: Motivies and Pressures to Adopt Green Management Practices. Corporate and Social Responsibility and Environmental Management, 18(1), 11-24. https://doi.org/10.1002/csr.229

Büyük, S. S. (2017). The Leaders in Social Responsibility in Turkey. Retrieved from http://www.capital.com.tr/expat-capital/the-leaders-in-social-responsibilityin turkey-haberdetay-2422

Cimatti, B., Campana, G., \& Carluccio, L. (2017). Eco Design and Sustainable Manufacturing in Fashion: A Case Study in Luxury Personal Accessories Industry. Procedia Manufacturing, 8, 393-400. https://doi.org/10.1016/j.promfg.2017.02.050

Corporate Social Responsibility Report on Turkish Textile an Apperel Industry. (2012). UN Joint Progrm MDGF 207 Harnessing Sustainable Linkages for SMEs in Turkey's in Turkey's Textile Sector.

De Brito, M. P., Carbone, V., \& Blanquart, C. M. (2008). Towards a Sustainable Fashion Retail Supply Chain in Europe: Organization and Performance. International Journal of Production Economics, 114, 534-553. https://doi.org/10.1016/j.ijpe.2007.06.012

Hasanbeigi, A., \& Price, L. (2015). A Techncal Review of Emerging Technologies for Energy. Journal of Cleaner Production, 95, 30-44. https://doi.org/10.1016/j.jclepro.2015.02.079

Jones, P., Comfort, D., \& Hillier, D. (2005). Corporate Social Responsibiliy and the UK Top Ten Retailers. International Journal of Retail and Distribution Management, 33(12), 882-892. https://doi.org/10.1108/09590550510634611 
Kiran-Ciliz, N. (2003). Reduction in resource consumpion by process modifications in cotton wet processes. Journal of Cleaner Production, 11, 481-486. https://doi.org/10.106/S0959-6526(02)00069-0

Kocabaş, A. M. (2008). Improvements in Energy and Water Consumption Performances of a Textile Mill after BAT Applications. Unpublished M.Sc. Thesis.

Lulewicz-Sas, A., \& Godlweska, J. (2013). Assesment of Environmental Issues of Corporate Social Responsibility by Enterprises in Poland-Results of Empirical Research. Procedia-Social and Behavioral Sciences, 533-538. https://doi.org/10.1016/j.sbspro.2015.11.446

Martinuzzi, A., Kudlak, R., Faber, C., \& Kimas, A. (2006). CSR Activities and Impacts of the Textile Sector. Rimas Working Papers, No-2/2011.

Öztürk, H. K. (2005). Energy Usage and Cost in Textile Industry: A Case Study for Turkey. Energy, 30, 2424-2446. https://doi.org/10.1016/j.energy.2004.11.014

Parsa, H. G., Lord, R. K., Kenneth, R. L., Putrevu, S., \& Kreeger, J. (2015). Corporate social and environmental responsibility in services: Will consumers pay for it? Journal of Retailing and Consumer Services, 22, 250-260. https://doi.org/10.1016/j.jretconser.2014.08.006

Pulat, E., Etemoğu, A. B., \& Can, M. (2009). Waste Heat Recovery Potential in Turkish Textile Industry: Case Study for the City of Bursa. Renewable and Sustainable Energy Reviews, 13, 663-672. https://doi.org/10.1016/j.rser.2007.10.002

Welford, R. (2005). Corporate social responsibility in Europe, North America and Asia, 2004 Survey Results. JCC17, Spring, Greenleaf Publishing, 33-52.

\section{Copyrights}

Copyright for this article is retained by the author, with first publication rights granted to the journal.

This is an open-access article distributed under the terms and conditions of the Creative Commons Attribution license (http://creativecommons.org/licenses/by/4.0/). 